\title{
Analisis Pengaruh Iklan, Harga dan Variasi Produk terhadap Keputusan Pembelian di Toko Rumah Pekanbaru
}

\author{
Astri Ayu Purwati ${ }^{1 *}$; Josua Julius Siahaan ${ }^{1}$; Zulfadli Hamzah ${ }^{2}$
}

\section{INFO ARTIKEL}

\section{Penulis:}

${ }^{\mathbf{1}}$ Program Studi Manajemen, STIE Pelita Indonesia, Pekanbaru, Indonesia

${ }^{2}$ Fakultas Agama Islam, Universitas Islam Riau, Pekanbaru, Indonesia

*E-mail: astri.ayu@lecturer.pelita indonesia.ac.id

\section{Untuk mengutip artikel ini:}

Purwati AA, Siahaan JJ \& Hamzah Z 2018, 'Analisis pengaruh iklan, harga dan variasi produk terhadap keputusan pembelian di toko rumah pekanbaru', Jurnal Ekonomi KIAT, vol. 30 , no. 1 , hal. $20-28$.

\section{Akses online:}

www.jurnalkiatuir.com

E-mail:

kiat@journal.uir.ac.id

\section{Di bawah lisensi: \\ Creative Commons Attribute- ShareAlike $4.0 \quad$ International Licence}

\begin{abstract}
AbStrak
Meningkatnya kebutuhan masyarakat terhadap mebel berpengaruh pada perdagangan industri. Untuk itu setiap toko bersaing dalam meningkatkan volume penjualan. Dengan semakin banyaknya toko yang bergerak dalam bidang yang sama, maka persaingan didunia usaha tersebut akan semakin meningkat.Tujuan penelitian ini adalah untuk mengetahui pengaruh Iklan, Harga, dan Varian Produk terhadap kepuasan konsumen toko Rumah Mebel Pekanbaru. Populasi dalam penelitian ini adalah konsumen yang melakukan pembelian produk di toko Rumah Pekanbaru. Jumlah sampel dalam penelitian ini adalah 100 responden yang merupakan pelanggan toko Rumah Mebel Pekanbaru. Hasil penelitian ini menunjukkan Harga dan Variasi Produk berpengaruh terhadap kepuasan konsumen di toko Rumah Pekanbaru dan hasil penelitian Iklan tidak berpengaruh terhadap kepuasan konsumen di toko Rumah Mebel Pekanbaru. Toko Rumah Mebel perlu memperhatikan Iklan yang dibuat, karena hal ini tidak berpengaruh terhadap pendekatan akan konsumen. Harga yang ditetapkan oleh rumah sesuai dengan perspsi dan konsumen mendapatkan potongan harga ini yang membuat harga mempengaruhi keputusan pembelian. Dan variasi produk yang dibuat oleh Rumah Mebel Pekanbaru sangat beragam seperti ukuran produk yang lengkap, jenis produk dan bahan produk juga mempengaruhi keputusan pembelian.
\end{abstract}

Katakunci: Harga, Iklan, Kepuasan Konsumen, Varian Produk

\section{Pendahuluan}

Perkembangan dunia usaha khususnya mebel ini semakin pesat. Hal ini membawa dampak terhadap sektor pembangunan di industri mebel. Pembangunan di bidang mebel ini diarahkan untuk memperlancar mobilitas serta pencapaian sarana pembangunan. Untuk itu diperlukan sarana perhubungan yang baik agar dapat memperlancar pencapaian sarana pembangunan tersebut.

Dengan semakin meningkatnya pertumbuhan ekonomi, kebutuhan setiap orang terhadap kebutuhan barang barang mebel semakian meningkat setiap tahunnya. Walaupun produk mebel bukanlah kebutuhan pokok, namun permintaan konsumen akan produk mebel semakin menanjak, dibuktikan juga kenaikan jumlah produsen, pabrik pabrik baru, dan toko toko mebel baru yang tiap tahun semakin meningkat.

Meningkatnya kebutuhan masyarakat terhadap mebel berpengaruh pada perdagangan industri. Untuk itu setiap toko bersaing dalam meningkatkan volume penjualan. Dengan semakin banyaknya toko yang bergerak dalam bidang yang sama, maka persaingan didunia usaha tersebut akan semakin meningkat.
Karena masing masing toko tersebut mempunyai hak dan kesempatan yang sama untuk menjalankan strategi penjualan dalam rangka meningkatkan volume penjualan yang pada akhirnya dapat meningkatkan laba toko. Kondisi ini berlaku untuk semua jenis usaha, termasuk pada toko yang bergerak dalam bidang mebel.

Persaingan dalam dunia bisnis yang semakin ketat membuat para pengusaha mencari strategi yang tepat untuk memasarkan produknya. Minat beli diperoleh dari suatu proses belajar dan proses pemikiran yang membentuk suatu persepsi. Minat pembelian ini menciptakan suatu motivasi dan keinginan yang sangat kuat yang pada akhirnya menyebabkan seorang pembeli harus mengaktualisasikan kebutuhan yang ada di benaknya itu.

Data grafik (Gambar 1) yang didapat dari badan pusat statistik pertumbuhan industri di indonesia fluktuatif setiap tahun nya, secara garis besar mengalami penurunan. Di tahun 2011 PDB industri furniture sebesar 22.000 miliar rupiah dengan pertumbuhan $11 \%$. Lalu di tahun 2012 PDB senilai 21.000 miliar rupiah dengan pertumbuhan anjlok ke angka -2\%. Di tahun 2013 terjadi perbaikan 
dengan PDB industri kembali 22.000 miliar dengan pertumbuhan industri furniture 4\%. Selanjutnya di tahun 2014 PDB meningkat menjadi 23.000 miliar dengan pertumbuhan stagnan di 4\%.Di tahun 2015 terjadi perbaikan masing masing untuk PDB senilai 24.000 miliar dan pertumbuhan di angka 4,5\%. Tahun 2016 baik PDB dan pertumbuhan kembali terkoreksi turun masing masing ke angka 9.000 miliar dan 1\%. Dapat disimpulkan bahwa PDB dan pertumbuhan industri furniture selalu berbeda setiap tahun nya. Mengindikasikan bahwa terjadi pergerakan masing masing penjual furniture. Pergerakan yang di artikan bahwa setiap tahun terdapat pemain pemain baru yang memulai usaha di bidang furniture dan ada beberapa pemain lama yang tidak dapat bertahan untuk terus berjualan furniture. Mengindikasikan terdapat faktor-faktor penting yang membuat sebuah perusahaan atau toko dapat bertahan, bahkan meningkatkan penjualannya. Demikian pula dalam faktor iklan, dengan menggandalkan iklan tentu toko kita akan terlihat berbeda dan seperti memiliki kelebihan di banding dengan toko lain. Disini promosi memiliki peranan yang sangat tinggi akan jumlah penjualan yang akan diterima toko. Persaingan bisnis menuntut setiap toko harus mampu bersikap dan bertindak cepat dan tepat dalam menghadapi persaingan di lingkungan bisnis yang bergerak sangat dinamis dan penuh dengan ketidakpastian. Oleh karena itu, setiap toko dituntut bersaing secara kompetitif dalam hal menciptakan dan mempertahankan pembeli yang loyal. Media yang digunakan rumah mebel untuk beriklan adalah Instagram, Facebook, OLX, Tokopedia.

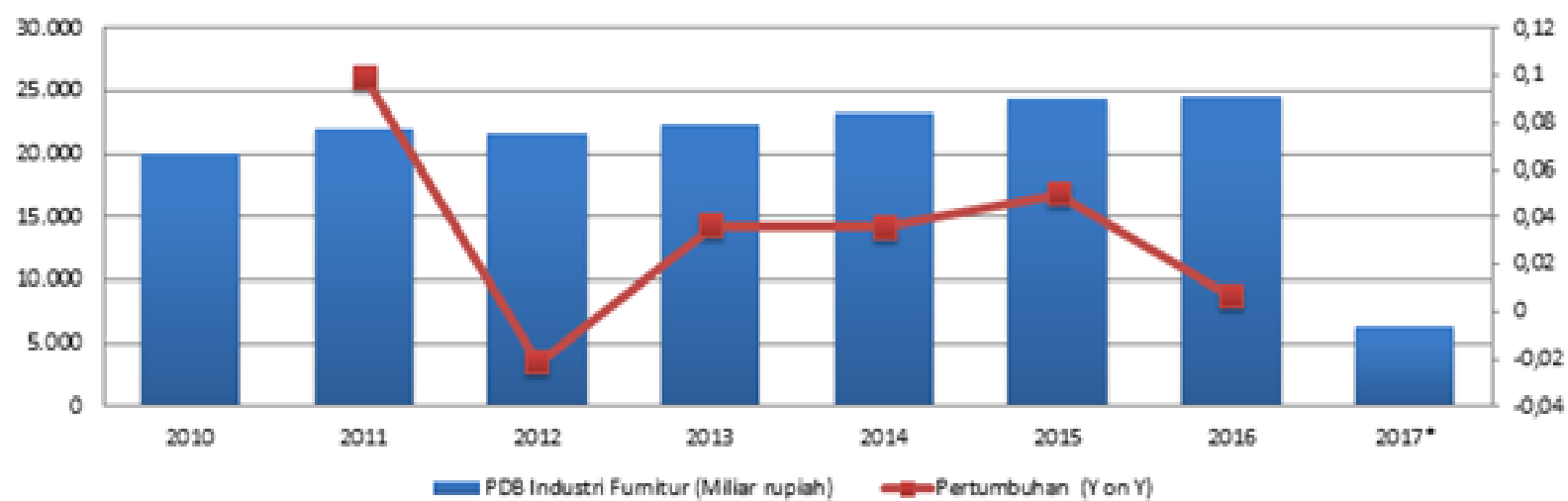

Gambar 1. Trend data pertumbuhan industri furniture di Indonesia tahun 2010 - 2017

Sumber: Badan Pusat Statistik (BPS), Bank Indonesia (BI)

Ketatnya persaingan dalam memperebutkan pasar yang begitu kompentitif antar toko di dalam kategori furniture saat ini menyebabkan berbagai permasalahan, salah satunya konsumen dihadapkan pada beberapa pilihan merek dengan produk dari toko lain yang bersaing di kategori usaha yang sama. Oleh karena itu agar tetap mampu bersaing perlu melakukan strategi variasi produk agar dapat menarik perhatian konsumen sehingga dapat mempengaruhi konsumen dalam melakukan keputusan pembelian. Toko-toko yang tidak mempunyai variasi produk dapat dengan mudahnya digeser dengan toko kompetitor yang memiliki produk yang sama. Semakin pasaran suatu produk yang ditawarkan suatu toko kepada konsumen, maka semakin banyak kompetitor yang langsung berhadapan dengan toko tersebut.

Menurut penelitian yang dilakukan (Atiq Arsyadani, 2015) disimpulkan harga berpengaruh signifikan terhadap keputusan pembelian di Minimarket Kopma, hal ini bertolak belakang dengan penelitian yang dilakukan oleh Yazia (2014) dimana harga berpengaruh negatif terhadap keputusan pembelian atau harga tidak berpengaruh terhadap keputusan pembelian.

Menurut penelitian yang dilakukan (Aziz, 2012)iklan berpengaruh positif terhadap keputusan pembelian handphone dual simcard buatan china, kembali bertolak belakang dengan penelitian yang dilakukan oleh (Asrul Siringo Ringo dan Yanti Mayasari Ginting, 2017) menunjukkan bahwa Variabel promosi tidak mempunyai pengaruh terhadap keputusan pembelian Springbed Kangaroo di PT. Anugrah Karya Aslindo. Hal ini berarti bahwa sering munculnya iklan tidak selalu mempengaruhi seseorang dalam melakukan keputusan pembelian.

Menurut penelitian yang dilakukan oleh (Indra Nurrahman, 2016) hasil penelitian menyatakan variasi produk berpengaruh positif dan signifikansi terhadap keputusan pembelian.

Adapun tujuan dalam penelitian ini adalah: 1) Untuk mengetahui pengaruh Iklan terhadap keputusan pembelian di Toko Rumah Mebel Pekanbaru; 2) Untuk mengetahui pengaruh harga terhadap keputusan pembelian di toko Rumah Mebel; 3)Untuk mengatahui pengaruh Variasi Produk terhadap keputusan pembelian di toko Rumah Mebel.

\section{Telaah Pustaka}

\subsection{Pemasaran}

Teori pemasaran Menurut (Ali, 2013) pemasaran adalah proses mengidentifikasi, menciptakan dan 
mengkomunikasikan nilai, serta memelihara hubungan yang memuaskan pelanggan untuk memaksimalkan keuntungan perusahaan.

Pemasaran merupakan salah satu dari kegiatankegiatan pokok yang dilakukan oleh para pengusaha dalam usahanya untuk mempertahankan kelangsungan hidupnya, untuk berkembang dan mendapatkan laba(Basu Swastha DH, 2008)

\subsection{Pengertian iklan}

Periklanan adalah satu dari empat alat penting yang digunakan oleh perusahaan untuk melancarkan komunikasi persuasif terhadap pembeli dan masyarakat yang ditargetkan. Pada dasarnya periklanan merupakan salah satubentuk komunikasi untuk memenuhi fungsi pemasaran. Periklanan harus mampu membujuk konsumen supaya berperilaku sedemikian rupa sesuai dengan strategi pemasaran pada perusahaan untuk mendapatkan penjualan dan laba.

Periklanan juga dipandang sebagai salah satu media yang paling efektif dalam mengkomunikasikan suatu produk dan jasa. Selain itu juga periklanan dibuat oleh setiap perusahaan tidak lain agar konsumen tertarik dan berharap tidak akan berpaling dari perusahaan yang sejenis lainnya, karena itu perusahanan harus menciptakan iklan yang semenarik mungkin.

Menurut Sandra Moriarty (2011) iklan adalah jenis komunikasi pemasaran yang merupakan istilah umum yang mengacu kepada semua bentuk teknik komunikasi yang digunakan pemasar untuk menjangkau dan menyampaikan pesan kepada konsumennya.

Adapun menurut (Tjiptono, 2012) menyatakan bahwa, Periklanan adalah bentuk komunikasi tidak langsung, yang didasari pada informasi tentang keungulan, atau keunggulan suatu produk, yang disusun sedemikian rupa sehingga menimbulkan rasa menyenangkan yang akan mengubah pikiran seseorang untuk melakukan pembelian.

\subsection{Indikator iklan}

Menurut (Setiadi, 2013), suatu iklan dapat dikatakan ideal apabila iklan tersebut: 1) Dapat menimbulkan perhatian Iklan yang ditayangkan hendaknya dapat menarik perhatian pemirsa, oleh karena itu iklan harus dibuat dengan gambar yang menarik, tulisan dan kombinasi warna yang serasi dan mencolok, serta kata-kata yang mengandung janji, jaminan, serta menunjukan kualitas produk yang diiklankan; 2) Menarik Iklan yang diberikan kepada pemirsa harus dapat menimbulkan perasaan ingin tahu dari konsumen untuk mengetahui merek yang diiklankan lebih mendalam, dan biasanya dilakukan dengan menggunakan figur iklan yang terkenal disertai dengan alur cerita yang menarik perhatian; 3) Dapat menimbulkan keinginan selain dapat menimbulkan perhatian dan menarik, sebuah iklan yang baik juga seharusnya dapat menimbulkan keinginan dalam diri konsumen untuk mencoba merek yang diiklankan. Dalam hal ini, penting bagi perusahaan untuk mengetahui motif dari pembelian konsumen, sebab dengan mengetahui apa yang menjadi keinginan dan kebutuhan konsumen. Dan melalui manfaat yang ditawarkan lewat iklan, perusahaan berharap untuk dapat mempengaruhi sikap konsumen, yang pada akhirnya dapat mendorong atau menimbukan keinginan konsumen untuk mencoba merek yang diiklankan; 4) Menghasilkan suatu tindakan setelah timbul keinginan yang kuat, maka konsumen akan mengambil tindakan untuk membeli merek yang diiklankan. Dan jika konsumen merasa puas dengan produk dari merek tersebut, maka konsumen akan mengkonsumsi atau melakukan pembelian ulang produk tersebut.

\subsection{Pengertian harga}

Menurut (Kotler \& Armstrong, 2013) harga adalah "The amount of money charged for a ptoduct or service, the sum of the values that customers exchange for the benefit of having or using the product or service".

Definisi lain dikemukakan oleh (Buchari Alma, 2013) mengemukakan bahwa harga adalah nilai suatu barang yang dinyatakan dengan uang. Sedangkan menurut (Schiffman dan Kanuk, 2008) mengemukakan bahwa harga adalah komponen yang menghasilkan pendapatan sedangkan yang lainnya menghasilkan biaya.

Berdasarkan dari beberapa definisi diatas maka peneliti sampai pada pemahaman bahwa harga adalah nilai dari suatu produk dalam bentuk uang yang harus dikorbankan konsumen guna mendapatkan produk, sedangkan dari produsen atau pedagang harga dapat menghasilkan pendapatan.

\subsection{Indikator harga}

Menurut (Kotler \& Amstrong, 2013) di dalam variabel harga ada beberapaa unsur kegiatan utama harga yang meliputi daftar harga, diskon, potongan harga dan periode pembayaran. Berikut adalah indikator yang dijadikan pengukuran harga dalam penelitian sebagai berikut: 1) Kesesuaian harga produk dengan kualitas produk maka konsumen akan melihat terlebih dahulu harga yang tercantum pada suatu produk, karena sebelum membeli konsumen sudah berpikir tentang sistem menghemat yang tepat. Selain itu konsumen dapat berpikir tentang harga yang ditawarkan memeiliki kesesuaian dengan produk yang telah dibeli (Schiffman dan Kanuk, 2008); 2) Daftar harga (list price) adalah informasi mengenai harga produk yang produk yang ditawarkan agar konsumen mempertimbangkan untuk membeli; 3) Potongan harga khusus (allowance) potongan harga khusus oleh potongan harga yang diberikan produsen/penjual kepada konsumen pada saat event tertentu; 4) Harga yang dipersepsikan yaitu persepsi pelanggan terhadap harga yang diterima, apakah tinggi, rendah atau adil. (Schiffman dan 
Kanuk, 2008).

Menurut (Kotler \& Amstrong, 2013) ada empat indikator mencirikan harga, yaitu: Keterjangkauan harga; Kesesuaian harga dengan kualitas produk; Daya saing harga; Kesesuaian harga dengan manfaat. Sedangkan menurut (Basu Swasta, 2008) indikator lainnya dapat diketahui, yaitu: Tingkat Harga; Potongan Harga; Waktu pembayaran dan Syarat Pembayaran.

\subsection{Pengertian variasi produk}

Menurut (Kotler \& Amstrong, 2013) mendefinisikan variasi produk sebagai unit tersendiri dalam suatu merek atau lini produk yang dapat dibedakan berdasarkan ukuran, harga, penampilan atau suatu ciri lain. Sedangkan menurut (Tjiptono, 2012), variasi produk cocok dipilih apabila perusahaan bermaksud memanfaatkan fleksibilitas produk sebagai strategi bersaing dengan para produsen misal produk-produk standar. Berdasarkan dari pengertian para ahli tersebut peneliti mengambil kesimpulan bahwa variasi produk adalah beraneka ragam produk yang didasari pada ukuran, harga, penampilan atau ciri-ciri lain sebagai usur-unsur pembedanya.

\subsection{Pengertian keputusan pembelian}

Menurut (Schiffman dan Kanuk, 2008), mendefinisikan keputusan sebagai pemilihan suatu tindakan dari dua pilihan alternatif atau lebih. Seorang konsumen yang hendak memilih harus memiliki pilihan alternatif.

Sedangkan menurut (Setiadi, 2013), mendefinisikan bahwa inti dari pengambilan keputusan konsumen adalah proses pengintegrasian yang mengombinasikan pengetahuan untuk mengevaluasi dua perilaku alternatif atau lebih, dan memilih salah satu di antaranya. Dalam keputusan membeli barang konsumen seringkali ada lebih dari dua pihak yang terlibat dalam proses pertukaran pembelian. Ada lima macam peranan yang dapat dilakukan seseorang, kelima peran ini dipegang oleh satu orang, namun seringkali pula peranan ini dilakukan beberapa orang.

\subsection{Kerangka pemikiran}

Kerangka pemikiran merupakan sintesa dari serangkaian teori yang tertuang dalam tinjauan pustaka, yang pada dsasarnya merupakan gambaran secara sistematis dari kinerja teori dalam memberikan solusi atau alternatif solusi dari serangkaian masalah yang ditetapkan (Djaslim Salidin, 2011). Maka digambarkan dalam bentuk skema kerangka pemikiran sebagai berikut:

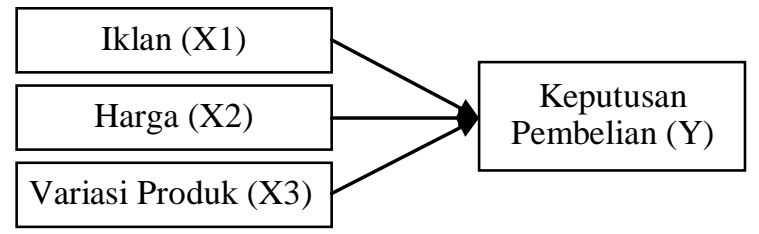

Gambar 2. Kerangka pemikiran

\subsection{Hipotesis}

Hipotesis merupakan suatu pernyataan sementara atau dugaan yang paling memungkinkan yang masih harus dicari kebenarannya.

Menurut (Sugiyono, 2010) hipotesis merupakan jawaban sementara terhadap rumusan masalah penelitian, dimana rumusan masalah penelitian telah dinyatakan dalam bentuk pertanyaan. Hipotesis dikatakan sementara dikarenakan jawaban yang diberikan baru didasarkan pada teori.

Adapun hipotesis dalam penelitian ini adalah: 1) Iklan berpengaruh signifikan terhadap Keputusan Pembelian di toko Rumah Mebel Pekanbaru; 2) Harga berpengaruh signifikan terhadap Keputusan Pembelian Teh Pucuk Harum Pada Mahasiswa Pelita Indonesia Pekanbaru; 3) Variasi Produk berpengaruh signifikan terhadap Keputusan di toko Rumah Mebel Pekanbaru.

\section{Metode Penelitian}

\subsection{Tempat dan waktu penelitian}

Tempat adalah lokasi di mana penelitian tersebut dilaksanakan. Penelitian ini dilakukan pada toko Rumah Mebel yang berlokasi di jalan Lintas Petapahan - Garuda Sakti No. 89 A, Simpang Baru, Tampan Kota Pekanbaru. Waktu penelitian dilakukan dari bulan Juli 2018 sampai dengan bulan September 2018.

\subsection{Populasi dan sampel}

Populasi adalah wilayah yang terdiri atas objek atau subjek yang mempunyai kualitas dan karakteristik tertentu yang ditetapkan oleh peneliti untuk dipelajari dan kemudian ditarik kesimpulannya (Sugiyono, 2010). Adapun yang menjadi populasi dalam penelitian ini adalah konsumen yang melakukan pembelian produk di toko Rumah Mebel Pekanbaru yang jumlahnya tidak diketahui secara pasti.

Sampel adalah bagian dari jumlah karakteristik yang dimiliki oleh populasi tersebut (Sugiyono, 2010) jumlah populasinya tidak diketahui secara pasti, oleh karena pihak toko Rumah Mebel Pekanbaru, tidak bisa secara pasti menghitung jumlah konsumen.

Dengan demikian, karena total variabel yang akan diteliti dalam penelitian ini adalah 3 variabel, yang terdiri dari 3 variabel bebas dan 1 variabel terikat, maka jumlah samppel yang digunakan sebanyak $4 \times 10=40$ orang responden. Terkait dengan sampel yang akan dikembangkan oleh responden, pasti tidak semua sampel dari pihak responden masing-masing dikembalikan atau lengkap sesuai dengan sampel yang kita bagikan. Maka penelitian ini mengambil jumlah responden menjadi 100 responden untuk diteliti.

\subsection{Teknik analisis data}

Adapun tahapan analisis data yang dilakukan dalam penelitian ini adalah sebagai berikut. 


\subsubsection{Uji validitas}

Uji validitas digunakan untuk mengetahui sah atau valid tidaknya suatu kueisoner. Suatu kuesioner dikatakan valid atau sah jika pertanyaan pada kuesioner mampu mengungkapkan sesuatu yang akan diukur oleh kuesioner tersebut (Ghozali. 2011).

\subsubsection{Uji reliabilitas}

Uji reliabilitas dilakukan untuk menjamin instrumen yang digunakan merupakan instrument handal dan dapat dipercaya sehingga apabila digunakan berulang-ulang maka akan mendapatkan hasil yang sama (Juliandi, 2013)

\subsubsection{Uji kelayakan model}

Uji F pada dasarnya menunjukkan apakah semua variabel bebas yang dimasukkan dalam model mempunyai pengaruh bersama-sama terhadap variabel terikat. Uji $\mathrm{F}$ digunakan untuk melihat secara bersama-sama variabel bebas yaitu: kualitas pelayanan, kualitas produk, dan promosi mempunyai pengaruh terhadap variabel terikat yaitu kepuasan konsumen.

\subsubsection{Uji koefisien determinasi $(R)$}

Uji koefisien determinasi $\left(\mathrm{R}^{2}\right)$ pada intinya mengukur seberapa jauh kemampuan model dalam menerangkan variasi variabel independen. Nilai koefisien determinasi adalah antara nol ddan satu. Nilai koefisien determinasi yang kecil berarti kemampuan variabel-variabel independen data menjelaskan variasi variabel dependen sangat terbatas.

Nilai yang mendekati satu berarti variabelvariabel independen memberikan hampir seluruh informasi yang dibutuhkan untuk memprediksi variasi variabel dependen. Tingkat kepercayaan yang digunakan dalam penelitian ini sebesar $95 \%$ atau (sebesar 5\%) proses analisis data menggunakan softwarepengolahan data Statistical Package for Sciene (SPSS) versi 16.0 untuk dapat mempermudah proses penelitan.

\subsubsection{Analisis regresi linier berganda}

Dalam menganalisa permasalahan dan pengujian hipotesis dalam penelitian inimaka peneliti menggunakan analisis regresi bergana (multiple regression). Analisis ini digunakan oleh peneliti, apabila peneliti bermaksud untuk meramalkan bagaimana keadaan variabel dependen, bila dua atau lebih independen sebagai faktor predictor dimanipulasi (naik turunnya nilai). Rumus untuk regresi berganda dalam penelitian ini adalah sebagai berikut :

$$
\mathrm{Y}=\mathbf{a}+\boldsymbol{\beta 1} \mathbf{X 1}+\boldsymbol{\beta 2} \mathbf{X 2}+\boldsymbol{\beta 3} \mathbf{X 3}+\mathrm{e}
$$

\subsubsection{Ujit}

Uji $\mathrm{T}$ digunakan untuk menguji secara parsial masing-masing variabel. Hasil uji t dapat dilihat pada tabel coefficients pada kolom sig (significance). Jika probabilitas nilai $\mathrm{t}$ atau signifikansi $<0,05$, maka dapat dikatakan bahwa terdapat pengaruh antara variabel bebas terhadap variabel terikat secara parsial. Namun, jika probabilitas nilai $\mathrm{t}$ atau signifikansi >0,05, maka dapat dikatakan bahwa tidak terdapat pengaruh yang signifikan antara masing-masing variabel bebas terhadap variabel terikat.

\section{Hasil Penelitian dan Pembahasan}

\subsection{Karakteristik responden}

Tabel 1. Demografi responden penelitian

\begin{tabular}{llcc}
\hline Demografi & Kategori & Frekuensi & Persentase (\%) \\
\hline \multirow{3}{*}{ Usia } & 20-29 tahun & 33 & 33 \\
& 30-39tahun & 38 & 38 \\
& $40-50$ tahun & 22 & 33 \\
Jenis Kelamin & diatas 50 tahun & 7 & 7 \\
\hline \multirow{4}{*}{ Pekerjaan } & Laki-laki & 46 & 46 \\
& Wanita & 54 & 54 \\
\hline & PNS & 15 & 15 \\
& Swasta & 35 & 35 \\
& Wiraswasta & 24 & 24 \\
Penghasilan & Mahasiswa & 0 & 0 \\
& Lainnya & 26 & 26 \\
\hline
\end{tabular}

Sumber: Data olahan (2018)

\subsection{Uji validitas}

Uji validitas digunakan untuk mengukur valid tidaknya suatu koesioner. Uji coba dilakukan setelah kuesioner selesai disusun dan diujicobakan pada sampel darimana populasi diambil. Pada kuesioner yang telah diuji menunjukkan bahwa semua pernyataan memiliki nilai $r$ hitung $>r$ tabel, yang artinya pernyataan disimpulkan valid. 


\subsection{Uji reliabilitas}

Uji reliabilitas menurut (Sugiyono, 2010) dilakukan untuk mengetahui seberapa jaug hasil pengukuran hasil pengukuran tetap konsisten apabila dilakukan pengukuran dua kali atau lebih tehadap gejala yang sama dengan menggunakan alat pengukur sama. Pengujian reabilitas dilakukan dengan menggunakan Cronbach Alpha.

Tabel 2. Hasil uji reliabilitas instrumen penelitian

\begin{tabular}{clccc}
\hline No & Variabel & Cronbanch's $\boldsymbol{\alpha}$ & Alpha & Keterangan \\
\hline 1 & Iklan (X1) & 0,648 & 0.6 & Reliabel \\
2 & Harga (X2) & 0,690 & 0.6 & Reliabel \\
3 & Variasi Produk (X3) & 0,728 & 0.6 & Reliabel \\
4 & Keputusan Pembelian (Y) & 0,677 & 0,6 & Reliabel \\
\hline
\end{tabular}

Sumber: Data olahan (2018)

\subsection{Uji kelayakan model}

Uji F dalam penelitian ini bertujuan untuk Pembelian.Dalam uji $\mathrm{F}$ ini, nilai yang digunakan mengetahui secara bersama-sama pengaruh Iklan, Harga dan Variasi Produk terhadap Keputusan adalah nilai $F$ dan nilai Sig yang terdapat dalam tabel ANOVA yang disajikan di bawah ini dalam Tabel 3.

Tabel 3. Hasil Pengujian Simultan (uji f)

\begin{tabular}{lllll}
\hline Model & $\mathrm{F}_{\text {hitung }}$ & $\mathrm{F}_{\text {tabel }}$ & Sig. & Keterangan \\
\hline $\mathrm{X}_{1}, \mathrm{X}_{2}, \mathrm{X}_{3}$ terhadap Y & 10,728 & 3,99 & $0,000^{\mathrm{a}}$ & $\begin{array}{l}\mathrm{X}_{1}, \mathrm{X}_{2}, \mathrm{X}_{3} \text { berpengaruh terhadap Y dengan } \\
\text { nilai Sig. }<\alpha=0.01\end{array}$ \\
\hline
\end{tabular}

Sumber: Data olahan (2018)

Hipotesis nol (Ho) yang digunakan dalam pengujian ini adalah tidak adanya pengaruh antara variabel independen secara bersama-sama terhadap variabel dependen. Sedangkan hipotesis alternatif (Ha) yang digunakan adalah terdapat adanya pengaruh antara variabel independen secara bersama-sama terhadap variabel dependen.

Berdasarkan atas hasil Tabel 3, $\alpha=0,01$ sebesar 3,99. dari hasil pengujian secara simultan (uji f) diperoleh hasil $F_{\text {hitung }}=10,728$, dengan nilai sig sebesar 0,000. Karena $F_{\text {hitung }} 10,728>F_{\text {tabel }} 3,99$ dan nilai signifikansi sebesar $0,000<0,01$, sehingga $\mathrm{H}_{0}$ ditolak dan $\mathrm{H}_{1}$ diterima yang artinya secara bersama-sama Iklan, Harga, Variasi Produk berpengaruh signifikan terhadap Keputusan Pembelian.

\subsection{Uji koefisien determinasi $\left(R^{2}\right)$}

Koefisien determinasi $\left(\mathrm{R}^{2}\right)$ digunakan untuk menjelaskan proporsi variabel dependen (bebas) yang mampu dijelaskan oleh variasi variabel independennya (terikat). Nilai koefisien determinasi adalah 0 $<2<1$. Nilai R2 yang kecil berarti kemampuan variabel indenpenden hampir memberikan semua informasi yang dibutuhkan untuk memprediksi variabel dependen. Kelemahan mendasar penggunaan koefisien determinasi adalah bias terhadap jumlah variabel dependen yang dimasukkan terhadap model. Oleh karena itu, banyak peneliti menganjurkan nilai adjusted $\mathrm{R}^{2}$ pada model regresi yang terbaik.

Tabel 4. Hasil uji koefisen determinasi $\left(\mathrm{R}^{2}\right)$

\begin{tabular}{rrrrr}
\hline Model & $\mathbf{R}$ & $\begin{array}{c}\mathbf{R} \\
\text { Square }\end{array}$ & $\begin{array}{c}\text { Adjusted R } \\
\text { Square }\end{array}$ & $\begin{array}{c}\text { Std Error of } \\
\text { the Estimate }\end{array}$ \\
\hline 1 & $0,501 \mathrm{a}$ & 0,251 & 0,228 & 0,45416 \\
\hline
\end{tabular}

Sumber: Data olahan (2018)

Berdasarkan pada tabel diatas ini menunjukan nilai Koefisien Determinasi (Adjusted $\mathrm{R}$ Square) sebesar 0,228. Hal ini artinya bahwa variasi Keputusan Pembelian dijelaskan olehIklan, Harga, variasi produk sebesar $22,8 \%$, sedangkan sisanya sebesar $77,2 \%$ dipengaruhi oleh variabel lainnya yang tidak diteliti dalam model.

\subsection{Regresi linear berganda}

Untuk melihat seberapa besar kualitas pelayanan, kualitas produk dan variasi produk terhadap keputusan pembelian maka digunakan analisis regresi liner berganda. Hasil uji Regresi Linier Berganda dapat dilihat pada tabel sebagai berikut:

Tabel 5. Hasil regresi linear berganda

\begin{tabular}{lccc}
\hline \multirow{2}{*}{ Model } & \multicolumn{2}{c}{ Unstandardized Coefficients } & Standardized Coefficients \\
\cline { 2 - 4 } & B & Std. Error & Beta \\
\hline Constant $)$ & 1,940 & 0,443 & \\
Iklan $\left(\mathrm{X}_{1}\right)$ & 0,054 & 0,083 & 0,059 \\
Harga $\left(\mathrm{X}_{2}\right)$ & 0,245 & 0,072 & 0,314 \\
Variasi produk $\left(\mathrm{X}_{3}\right)$ & 0,240 & 0,072 & 0,303 \\
\hline
\end{tabular}

Sumber: Data olahan (2018) 
Berdasarkan pada Tabel 5 di atas, maka persamaan regresi linier berganda dalam penelitian ini adalah:

\section{$\mathrm{Y}=1,940+0,054 \times 1+0,245 \times 2+0,240 \times 3+e$}

Persamaan regresi linier berganda di atas dapat dijelaskan sebagai berikut: 1) 0, maka Keputusan Pembelian nilainya adalah 1,940 satuan; 2) Nilai koefisen regresi linier berganda variabel Iklan sebesar 0,054 yang berarti jika variabel independen lainya tetap dan iklan mengalami kenaikan 1 satuan, maka keputusan pembelian akan mengalami kenaikan sebesar 0,054 satuan. Koefisen bernilai positif artinya terjadi hubungan positif, di mana Iklan yang rendah akan meningkatkan Keputusan Pembelian; 3) Nilai koefisen regresi linier berganda variabel Harga sebesar 0,245 yang berarti jika variabel independen lainya tetap dan Harga mengalami kenaikan 1 satuan, maka Keputusan Pembelian akan mengalami kenaikan sebesar 0,245 satuan. Koefisen bernilai positif artinya terjadi hubungan positif, di mana Harga yang tinggi akan meningkatkan Keputusan Pembelian; 4) Nilai koefisien regresi linier berganda variabel Variasi produk sebesar 0,240 yang berarti jika variabel independen lainnya tetap dan Variasi produk mengalami kenaikan 1 satuan, maka Keputusan Pembelian akan mengalami kenaikan sebesar 0,240 satuan. Koefisen bernilai positif artinya terjadi hubungan positif, di mana Variasi Produk yang tinggi akan meningkatkan Keputusan Pembelian.

\subsection{Uji parsial (uji t)}

Uji t digunakan untuk menguji signifikansi hubungan antara variable $\mathrm{X}$ dan variabel $\mathrm{Y}$. Berikut adalah hasil perhitungan uji $\mathrm{t}$ :

Tabel 6. Hasil pengujian parameter individual (uji t)

\begin{tabular}{lccll}
\hline Model & $\mathbf{T}_{\text {hitung }}$ & $\mathbf{T}_{\text {tabel }}$ & Sig & Keterangan \\
\hline Iklan $\left(\mathrm{X}_{1}\right)$ & 0,654 & 1,2903 & 0,515 & Tidak Berpengaruh signifikan \\
Harga $\left(\mathrm{X}_{2}\right)$ & 3,393 & 2,3654 & $0,001^{* * *}$ & Berpengaruh signifikan dengan $\alpha 0,01$ \\
Variasi produk $\left(\mathrm{X}_{3}\right)$ & 3,317 & 2,3654 & $0,001^{* * *}$ & Berpengaruh signifikan dengan $\alpha 0,01$ \\
\hline
\end{tabular}

Sumber: Data olahan (2018)

Berdasarkan tabel diatas, maka hasil pengujian secara parsial dapat dijelaskan sebagai berikut: 1) Hipotesis 1 artinya hasil pengujian menun-jukkan bahwa nilai $\mathrm{T}_{\text {hitung }}$ untuk variabel Iklan sebesar 0,654 $<$ dari $\mathrm{T}_{\text {tabel }}$ sebesar 1,2903 atau nilai signifikan 0.515 $>$ dari alpha 0,1 maka $\mathrm{H}_{1}$ ditolak, dengan berarti bahwa variabel Iklan tidak berpengaruh signifikan terhadap Keputusan Pembelian di toko Rumah Mebel Pekanbaru; 2) Hipotesis 2 artinya hasil pengujian menunjukkan bahwa nilai $\mathrm{T}_{\text {hitung }}$ untuk variabel Harga sebesar 3,393> dari $\mathrm{T}_{\text {tabel }}$ sebesar 2,3654 atau nilai signifikan $0.001<$ dari alpha 0.01 , maka $\mathrm{H}_{2}$ diterima, dengan berarti bahwa variabel Harga berpengaruh signifikan terhadap Keputusan Pembelian di toko Rumah Mebel Pekanbaru; 3) Hipotesis 3 artinya hasil pengujian menunjukkan bahwa nilai $\mathrm{T}$ hitung untuk variabel Variasi Produk sebesar 3,317 > dari $\mathrm{T}_{\text {tabel }}$ sebesar 2,3654 atau nilai signifikan $0.001<$ dari alpha 0.01 , maka $\mathrm{H}_{3}$ diterima, dengan berarti bahwa variabel Variasi Produk berpengaruh signifikan terhadap Keputusan Pembelian di toko Rumah Mebel Pekanbaru

\subsection{Pembahasan}

Sebagaimana yang telah diuraikan sebelumnya bahwa penelitian ini bertujuan untuk pengetahui pengaruh Iklan, Harga, Variasi Produk terhadap Keputusan Pembelian di toko Rumah Mebel Pekanbaru. Dengan demikian pembahasan penelitian yang dilakukan adalah untuk melihat signifikan pengaruh Iklan, Harga, Variasi Produk terhadap Keputusan Pembelian di toko Rumah Mebel Pekanbaru.
Berdasarkan hasil deskriptif tanggapan responden dapat dilihat bahwa nilai total rata-rata Iklan $\left(\mathrm{X}_{1}\right)$ tergolong dalam kategori yang baik. Diketahui nilai rata-rata tertinggi terdapat pada pernyataan saya bukan hanya mencari tahu tetapi juga membeli produk yang dijual dirumah mebel pekanbaru. Sedangkan pernyataan terendah terdapat pada pernyataan iklan yang dibuat menimbulkan perhatian. Hal ini memperlihatkan bahwa toko Rumah Mebel masih harus meningkatkan kualitas dari pernyataan iklan yang dibuat.

Berdasarkan hail uji t diketahui bahwa variabel Iklan memiliki tidak pengaruh yang signifikan terhadap Keputusan Pembelian. Dengan demikian secara parsial dapat dinyatakan variabel iklan tidak berpengaruh nyata terhadap keputusan pembelian di toko Rumah Mebel Pekanbaru. Pada umunya konsumen mendapatkan informasi mengenai iklan yang dibuat, dan membuat komnsumen untuk membeli produk di toko Rumah Mebel. Sebagaimana yang diungkapkan oleh (Djaslim Salidin, 2011) iklan adalah sebagai bentuk komunikasi nonpersonal yang menjual pesan-pesan persuasif dari sponsor yang jelas untuk mempengaruhi orang membeli produk dengan membayar sejumlah biaya untuk media.

Dari hasil penelitian yang dilakukan oleh peneliti terdahulu yaitu (Studi, Pada, Stie, \& Bogor, 2018) bahwa iklan memiliki pengaruh yang signifikan terhadap keputusan pembelian. Penelitian sebelumnya tidak sejalan dengan penelitian yang dilakukan saat ini bahwa variabel Iklan tidak berpengaruh terhadap Keputusan Pembelian di toko Rumah Mebel Pekanbaru. 
Berdasarkan hasil deskriptif tanggapan responden dapat dilihat bahwa nilai total rata-rata harga $\left(\mathrm{X}_{2}\right)$ tergolong dalam kategori yang baik. Diketahui nilai rata-rata terdapat pada penyataan Rumah mebel memberikan potongan hargadan hargaharga disana seuai dengan persepsi saya. Dan indikator terendah terdapat pada pernyataan Rumah Mebel memiliki harga yang memudahkan dalam pemilihan produk yang akan dibeli. Hal ini memperlihatkan bahwa toko Rumah Mebel memiliki daftar harga yang memudahkan dalam pemilihan produk dan memberikan potongan harga

Berdasarkan hasil uji t diketahui bahwa variabel Harga memiliki pengaruh yang signifikan terhadap Keputusan Pembelian. Dengan demikian secara parsial dapat dinyatakan variabel harga berpengaruh nyata terhadap keputusan pembelian di toko Rumah Mebel Pekanbaru, mengingat bahwasanya dalam membeli suatu produk konsumen akan selalu mempertimbangkan harga. Sebagaimana yang diungkapkan oleh (Djaslim Salidin, 2011) harga adalah mengemukkan bahwa konsumen mengharapkan harga yang sepadan dengan kualitas produk dari pembelian yang dilakukan.

Dari hasil penelitian yang dilakukan oleh peneliti terdahulu yaitu (P. Made, 2017) bahwa harga memiliki pengaruh yang signifikan terhadap keputusan pembelian. Penelitian sebelumnya sejalan dengan penelitian yang dilakukan saat ini bahwa variabel harga berpengaruh terhadap keputusan pembelian di toko Rumah Mebel Pekanbaru.

Berdasarkan hasil deskriptif tanggapan responden dapat dilihat bahwa nilai total rata-rata variasi produk $\left(\mathrm{X}_{3}\right)$ tergolong dalam kategori yang baik. Diketahui nilai rata-rata tertinggi terdapat pada pernyataan memiliki desain produk yang unik dan beragam. Sedangkan pernyataan terendah terdapat pada pernyataan memiliki ukuran produk yang lengkap dan beragam.

Berdasarkan hail uji t diketahui bahwa variabel Variasi Produk memiliki pengaruh yang signifikan terhadap Keputusan Pembelian. Dengan demikian secara parsial dapat dinyatakan variabel Variasi Produk berpengaruh nyata terhadap Keputusan Pembelian konsumen di toko Rumah Mebel Pekanbaru, hasil penelitian ini menunjukkan bahwa

\section{Referensi}

Ali, H. (2011). Marketing dan Kasus-kasus Pilihan. In CAPS Yogyakarta (Ed.), CAPS (Center For Academic Publishing Service) (cetakan 2).

Arsyadani, Atiq. (2015). Pengaruh Harga dan Keragaman Produk terhadap Keputusan Pembelian di Minimarket KOPMA Walisongo Semarang. Universitas Islam Negeri Walisongo. Jurnal Manajemen Dan Akuntansi, 02(04).

Aziz, R. A. (2012). Pengaruh Iklan dan Harga terhadap Keputusan Pembelian Handphone Dual bermacam-macam produk yang dijual akan membuat ketertarikan konsumen untuk membeli produk yang ada di rumah Mebel Pekanbaru. Variasi produk adalah hal penting yang harus diperhatikan oleh perusahaan untuk meningkakan kinerja produk, jika produk tersebut tidak beragam maka produk tersebut tentu akan kalah bersaing dengan produk yang lain.

Dari hasil penelitian yang dilakukan oleh peneliti terdahulu yaitu (Indra Nurrahman, 2016) bahwa variasi produk tidak memiliki pengaruh yang signifikan terhadap keputusan pembelian, penelitian sebelumnya tidak sejalan atau terdapat perbedaan dengan penelitian yang dilakukan saat ini bahwa variabel Variasi Produk berpengaruh signifikan terhadap Keputusan Pembelian di toko Rumah Mebel Pekanbaru.

\section{Simpulan}

Berdasarkan hasil penelitian, dapat ditarik kesimpulan: 1) Harga dan Variasi Produk berpengaruh signifikan terhadap Keputusan Pembelian di toko Rumah Mebel Pekanbaru; 2) Iklan tidak berpengaruh signifikan terhadap Keputusan Pembelian di toko Rumah Mebel Pekanbaru.

\section{Saran}

Berdasarkan hasil pembahasan dalam penelitian ini, maka penulis memberikan saran: 1) toko Rumah Mebel perlu memperhatian akan Iklan yang dibuat, karena hal ini tidak berpengaruh terhadap pendekatan akan konsumen. Harga yang ditetap kan oleh rumah Mebel sesuai dengan perspsi dan konsumen mendapatkan potongan harga ini yang membuat harga mempengaruhi keputusan pembelian. Dan variasi produk yang dibuat oleh rumah Mebel Pekanbaru sangat beragam seperti ukuran produk yang lengkap, jenis produk dan bahan produk juga mempengaruhi keputusan pembelian; 2) Bagi Akademis, hasil dari penelitian ini dapat dijadikan sebagai penambah referensi oleh pihak lain yang melakukan penelitian untuk permasalahan yang sama dimasa yang akan datang, dan bagi peneliti selanjutnya diharapkan dapat menambah variabel lain diluar variabel yang sudah diteliti dalam penelitian ini agar memperoleh hasil yang bervariasi yang dapat berpengaruh terhadap keputusan pembelian.

Simcard buatan China pada Mahasiswa Fakultas Ekonomi Universitas Negeri Yogyakarta.

Buchari. Alma. 2013. Manajemen Pemasaran dan Pemasaran Jasa. Edisi 2. Alfabeta. Bandung.

Ghozali, I. 2011. Aplikasi Analisis Multivariate dengan Program SPSS. In S. P. B. U. Diponegoro (Ed.).

Juliandi, A. 2013. Metedelogi Penelitian Kuantitatif Untuk Ilmu-Ilmu Bisnis. In Medan:M2000 (Ed.). 
Kotler, Philip dan Gary Armstrong. 2013. Prinsipprinsip Pemasaran. Kelompok Gramedia.Jakarta.

Muhammad Gigih Made P. 2017. Pengaruh Promosi dan Harga Terhadap Keputusan Pembelian Surat KabarHarian Surat Merdeka. Jurnal Manajemen Dan Akuntansi. Jakarta

Nurrahman, Indra, D. H. U. (2016). Pengaruh Variasi Produk terhadap Keputusan Pembelian (Survei pada pembeli Smartphone Nokia series $\mathrm{X}$ di BEC Bandung), 1(1), 54-63.

Ringo, Asrul Siringo dan Yanti Mayasari Ginting. (2017). Analisis Pengaruh Produk, Harga, Promosi, Tempat terhadap Keputusan Pembelian pada Produk Springbed Kangaroo di Pekanbaru.

Rendra Setiadi Tri Pujadi. (2010). Aplikasi EMarketing pada PT Buana Jaya Paperindo Seminar Nasional Aplikasi Teknologi Informasi $2010, b-48, b-55$.

Salidin, Djaslim. 2011. Manajemen Pemasaran. Agung Ilmu. Bandung.

Sandra Moriarty, N. M. dan W. W. (2011). Advertising. In K. P. M. Group (Ed.) (08 ed.). Jakarta.
Setiadi.2013. Perilaku Konsumen. Edisi Revisi. Jakarta: Kencana Prenada Media Group.

Schiffman dan Kanuk.2008. Perilaku Konsumen. Edisi 7. PT.Indeks. Jakarta

Studi, D., Pada, K., Stie, M., \& Bogor, K. (2018). Pengaruh iklan terhadap keputusan pembelian pada pt. djojonegoro (studi kasus pada mahasiswa stie kesatuan bogor), (November 2012).

Sugiyono. 2010. Metode Penelitian Bisnis (Pendekatan Kuantitatif, Kualitatif, dan $R \& D)$. Alfabeta. Bandung.

Swastha, Basu DH, I. (2008). Manajemen Pemasaran Modern. In Liberty Offset (Ed.) (Edisi 02,).

Tjiptono. 2012. Strategi Pemasaran. Edisi 3. ANDI. Yogyakarta.

Yazia, V. (2014). Pengaruh Kualitas Produk , Harga, dan Iklan terhadap Keputusan Pembelian Handphone Blackberry (Study Kasus Blackberry Center Veteran Padang). Journal of Economic and Economic Education, 02(165-173). 